\title{
A Promising Family Literacy Project Based on Male Reading Models
}

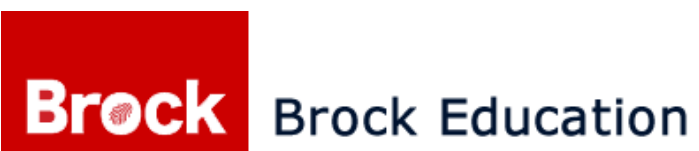

A journal of educational research and practice 2021 Vol. 30 (1) 51-73

https://journals.library.brocku.ca/brocked

\author{
Isabelle Carignan 1*, Robin L. Quick², Marie-Christine Beaudry³, Alexandra Deck", \\ France Beauregard 5 , Annie Roy-Charland 6 \\ 1 TÉLUQ University \\ 2 Gannon University \\ 3 Université du Québec à Montréal \\ 4 Laurentian University \\ 5 University of Sherbrooke \\ 6 University of Moncton
}

\begin{abstract}
This article discusses an innovative family literacy project that was implemented in a community setting. Male trios consisting of a male significant figure, a struggling reader in elementary school, and a pre-service teacher were created. The goal was (a) to develop the student's motivation to read by using a male reading role model and allowing the student to read what he truly enjoys in a non-school environment and (b) document reading practices as trios. To document the progression of four trios, we used a semi-directed interview, a focus group, and a logbook. The results of this multiple-case research study showed an improvement regarding the student's motivation to read in the context of male trios, different reading practices inside the trios, and a positive evolution in the relationship between the student and participating male relative.

Keywords: family literacy, male reading model, motivation, father-child relationship, community literacy

* isabelle.carignan@teluq.ca
\end{abstract}




\section{Background}

The "Reading with my buddy" project (Lire avec fiston in French) was initially created in Quebec, Canada to enhance the reading desire in young male students with reading difficulties or with no motivation to read (Beauregard \& Carignan, 2010, 2012; Carignan \& Beauregard, 2010). It was a request from the school settings; they wanted reading projects with boys in elementary school to develop their interests, especially to counter school dropout later on. The project matched male students in Grades 3 and 4, who were identified as struggling readers, with a male significant figure and a male pre-service teacher. The objective of this project was to develop an enjoyment for reading not only by engaging the boys' personal interests (Conseil canadien sur l'apprentissage, 2010), but also by including a male figure as a positive reading model. From there, "Reading with my buddy" was born, a family literacy project that was later adapted to family and community literacy in Pennsylvania.

Historically, young boys have struggled more in an academic setting than young girls have, especially when it comes to reading capabilities (Boerma et al., 2016; Bouchamma et al., 2014; Chiu, 2018). In fact, boys have demonstrated a higher dropout rate in early year education when compared to their female peers (Cairns et al., 1989). Statistics Canada found that in the 2009/2010 Labour Force Survey, the high school dropout rate for boys was 10.3\%, which was significantly higher than that of girls at $6.6 \%$ (Gilmore, 2010). Dropping out in high school can stem from issues present in a child's primary school education years. Whereas factors such as socioeconomic status play a large part, one cannot discount the effect that academic struggle has on the prevalence of school dropouts. Walsh et al. (2015) found that increased elementary school student support leads to a lower high school dropout rate. Prior research has indicated that young boys have a more negative attitude when it comes to school than girls do (Logan \& Johnston, 2009). A child's attitude is an important factor that has heavy influence over their motivation, level of enjoyment, and achievement (Logan \& Johnston, 2009). It has been found that struggling in certain academic domains, like reading, has been correlated with increased dropout rates (Korhonen et al., 2014). Failing to complete primary school or even high school will seriously limit a child's future opportunities. Ultimately, we strive to find strategies that will encourage boys to reach their full potential and continue on in their education.

The underlying focus of "Reading with my buddy" is to overcome the lack of motivation to read among male students. Research has uncovered a myriad of reasons for the lack of motivation in young boys. One reason is that boys associate reading with school purposes such as taking evaluations (Bloome et al., 2000; Serafini, 2013 ; Ward \& Wason-Ellam, 2005). Moreover, traditional classroom curriculum books are not necessarily designed for boys. They often fail to motivate them to read based on curiosity or interests (Gritter et al., 2017). It has also been shown that the lack of male reading role models is a factor. The absence of male reading role 
models perpetuates the common perception that reading is a female activity (Baron, 1996; Clark \& Picton, 2012; Lavoie \& Fontaine, 2016; McKenna, 1997; Pronovost, 2013).

It is important to highlight and address the gendered issue that is consistently present when examining young boys' and girls' reading tendencies. Ideally, creating equal environments and opportunities for young boys and girls to succeed as readers would help to eradicate the imbalance between the genders. Whether or not we fail to acknowledge the gender discrepancies, differences among boys' and girls' reading capabilities and desires have been consistently documented; girls tend to be more enthusiastic readers, as well as more competent and motivated readers (Farukh et al., 2020; Ozturk et al., 2016; Reilly et al., 2019; Stoet \& Geary, 2013; van Hek et al., 2019). There could be several explanations for this discrepancy. For example, there might be a lack of male role models in schools. There are fewer male teachers in primary school and early education. This could be due in part to gender stereotypes present in the educational field. Mistry and Sood (2012) found that men do have an interest in pursuing careers in education, but they need the encouragement from other strong male mentors to help break the barriers. These barriers are simply present due to the stereotypes that exist around males in the educational setting, especially in early year educators.

Furthermore, another explanation could be young males more often tend to have poorer reading motivation (De Naeghel et al., 2012; McGeown et al., 2012). Reading has been typically associated with the female identity. Indeed, McGeown et al. (2012) found that while there was not always a large difference in reading ability, females showed higher reading motivation. Aiming for gender neutrality and equal support in children's upbringing can help to even the playing field and encourage both males and females to become strong readers across all contexts. McGeown et al. (2012) emphasized the difference between sex and gender and found that predictions of motivation deal more with gender identity and stereotypes.

As such, all of these factors can combine to create a gendered environment that sees more young girls succeeding than young boys (Boerma et al., 2016; Chiu, 2018; Wolter et al., 2015). Finding more ways to get boys active and involved in reading can improve their attitudes, enjoyment, and level of achievement (Smith, 2017). Researchers behind the "Reading with my buddy" project set out to further investigate these motivational issues and determine if male reading role models could have a positive impact in overcoming them. The Quebec project was conducted between 2008 and 2010 and serviced 13 children. It was recreated in Pennsylvania in 2011 and serviced four children. This article focuses on data from the "Reading with my buddy" project in Pennsylvania. Both versions of the "Reading with my buddy" project (Quebec and Pennsylvania) maintained the male trio format and focused on the fact that reading can be friendly and fun. The two main differences in execution were that the trios in the Canadian project met inside the family home, while the trios in Pennsylvania met within the community. 


\section{Review of Literature}

The "Reading with my buddy" project seeks to increase young boys' understanding and enjoyment of literacy through group reading activities with strong male reading role models. Throughout this project, the student-mentor groupings work to shift the child's perspective about reading in a positive direction. It has been found that both father-child relationships and shared book reading is instrumental in this process. Young boys tend to consider reading as a mandatory school component, as opposed to an enjoyable activity that promotes cognitive development and socialization. Projects that promote family or group reading activities have been found to not only promote the development of reading skills (Ezell \& Justice, 2000; Justice \& Ezell, 2000) but also strengthen interpersonal bonds (Karther, 2002; Morgan et al., 2009; Saracho, 2008). Throughout the process of "Reading with my buddy", young boys are given the opportunity to explore reading material they enjoy, in hopes of promoting their reading motivation and enjoyment.

\section{A Definition of Literacy}

Literacy is described as the development "of the ability to read, to write, to speak and to listen. In addition, these "literacy" practices can be used in everyday life, at home, at work, in school, or in the community, depending on the goals of each individual, in interaction with their own values and their own culture" (Beauregard et al., 2011 , p. 8). Literacy is often considered to be a cognitive process, but is also a social activity (Cairney, 2002) that takes place in a social context in which children could "participate with others, notably parents, family members, peers and teachers in the activities that constitute the culture in which they are growing up" (Wells, 2009, p. 271). Some children perceive reading as a collaborative or even a communal activity. These are children who read books with their family. In this case, it is called family literacy. This term has been used for more few decades and is defined as follows:

As discourse, family literacy is inclusive for the oral and written communications within the family and it encompasses the family's efforts to support the language and literacy development of their children. ... Scott, Brown, Jean-Baptiste $\&$ Barbarin stress the need to be inclusive of family beliefs and values when considering services to families.

Furthermore, using the oral traditions and cultural heritage of families can provide a creative and empowering means of helping families develop writing and reading skills important for many everyday functions, and can potentially serve as a foundation for more advanced literacy development. (Adra, 2004, as cited in Wasik \& Van Horn, 2012, pp. 5-6)

\section{Children's Perceptions About Reading}

Due to its duality as a cognitive and social activity (Cairney, 2002), two specific factors appear to influence children's perceptions about reading: the purpose of reading and their parents' perceptions about reading (Beauregard et al., 201 1; Clark \& Picton, 2012). In fact, many 
children do not understand the purpose of reading, especially boys and often link it to academia (Bloome et al., 2000; Serafini, 2013; Ward \& Wason-Ellam, 2005). This is true especially for children who have negative attitudes toward reading (Bursuck et al., 2010). Good readers often see reading as friendly and amusing and thus enjoy reading (Chiu \& Ko, 2005). It is important for reading to be meaningful for children. Boys in particular prefer reading that helps "deepen existing areas of expertise" in a topic or genre they enjoy (Wilhelm \& Smith, 2014 , p. 274) and enjoy reading that is related to their lives (Saracho, 2008). For these reasons, in order to involve children in a family literacy project, the focus must be on reading enjoyment (Baugh, 2017; Beauregard \& Carignan, 2010; Carignan \& Beauregard, 2010; Collins \& Matthey, 2001). The second factor influencing children's perceptions of reading is how their parents perceive reading (Baker, 2003; Baker \& Scher 2002; Nalipay et al., 2020). These perceptions strongly affect their level of commitment to a family literacy program (Wiseman, 2009).

\section{Importance of Male Reading Models}

Several researchers have turned their attention to the family-school-community relationship and have shown that parent involvement, especially fathers, has a significant impact on improving self-esteem, lowering absenteeism, and increasing adequate behaviours with regard to school (Epstein, 2001; Hoover-Dempsey et al., 2005). Multiple studies on family literacy projects show that these programs enable the parent and child to develop a significant bond (Anderson et al., 2010; Baker, 2003). Studies have also shown that children are motivated to read by family members (Edmunds \& Bauserman, 2006), most often the mother (Lavoie \& Fontaine, 2016). The importance of having a male role model is accepted by many educators (Carrington \& McPhee, 2008). Solutions to motivating children to read include getting more men involved in teaching, and more fathers actively reading with their sons to show them that reading is also a male activity (Smith, 2017). Summers (2013) found "a product of the predominance of female teachers versus male teachers, which contributes to boys' perception of reading as being a feminine pursuit" (p. 244). Using male role models including "fathers, grandfathers, or other male volunteers" is important to motivate elementary boys to read (Gurian \& Stevens, 2004, p. 25). Shared book reading (Roy-Charland et al., 2007) is an interesting way to make an association between the act of reading and the father and son relationship (Bergin, 2001; Bus \& Van IJzendoorn, 1998).

\section{Importance of Father-Child Relationship}

A few studies have investigated the place of fathers in a family literacy project. Interestingly, fathers select readings based on their own interests and those of their children (Saracho, 2008). Thus, they are just as likely to read a children's literature book as to read non-fiction books or magazines. Similarly, fathers may use the same reading strategy for different purposes. For example, some fathers encourage their children to read from pictures because it is better for 
the children to read their own story and it allows the children to interpret the story in their own way (Karther, 2002; Morgan et al., 2009; Saracho, 2008). In fact, some studies have shown that fathers interact more than mothers in a shared book reading activity (Anderson et al., 2004). Fathers' involvement in family literacy programs can also have a significant impact on their parental practices and on "the important role they play in supporting their children's literacy" (Clark \& Picton, 2012, p. 7). Family literacy projects with fathers can strengthen the bond (Carignan et al., 2015) they have with their children (Karther, 2002; Morgan et al., 2009; Saracho, 2008). These studies showed the importance of including fathers in family literacy programs because fathers bring their own personal perspective, which may be different from the mothers (Beauregard et al., 2011). This is one reason why the "Reading with my buddy" project was proposed. This approach brings a unique perspective regarding male reading models by including male pre-service teachers, and is another way of perceiving family literacy and community literacy through shared book reading (Carignan et al., 2013).

\section{Importance of Shared Book Reading}

Shared book reading is a broad terminology that refers to several types of specific reading activities. Among other things, it includes parents who read a book before the child's bedtime, or teachers who read a book to an entire group at school, or co-reading between an adult and a child or between peers (Roy-Charland et al., 2007; Smith, 2017; Van Kleeck et al., 2003). Joint reading, in which the adult and child take turns leading the reading of the text, is also among many children's favourite learning activities. Several studies on shared book reading examine this activity from different angles. Research in this area focuses on two main aspects: cognitive achievement and emotional development arising from the practice of this activity. On the one hand, studies have focused on the impact of this activity on development of reading skills (e.g., Bus et al., 1995; Ezell \& Justice, 2000; Justice \& Ezell, 2000). On the other hand, although fewer studies have explored this component, researchers have identified a link between the practice of shared reading and emotional development factors in children such as the interest and motivation for reading or the link with secure attachment (Bus \& van IJzendoorn, 1998; Frosch et al., 2001). Regardless of the purpose, children typically say that of all activities related to literacy, shared reading is their preferred format. Thus, the choice of this strategy is well rooted.

The objectives of this family literacy project were to (a) develop the student's motivation to read by using male reading role models and allowing the student to read what he truly enjoys in a non-school environment and (b) document reading practices as male trios.

\section{Methods}

This study adopted a qualitative descriptive research design. This is a "method of choice when straight descriptions of phenomena are desired" (Sandelowski, 2000, p. 339; Maxwell, 1992). 
This is also an exploratory research because it is a "preliminary stage in the research process that gives way-the sooner the better-to the real thing" (Stebbins, 2001, p. 5) and to multiple discoveries. This research is also a case study; more specifically, a multiple-case research "used to predict similar results" (Barone, 2011 , p. 22). In fact, this study offers information about the dynamic and the learning (Dyson, 1995) of everyone inside the male trios during the family literacy project.

\section{Participants}

\section{Selection of the Male Teacher Candidates}

A few months prior to the project's start, a professor from Erie, Pennsylvania, was contacted to collaborate in the project. She took over recruitment of the male teacher candidates. Several male teacher candidates in the Elementary Education program at Gannon University were invited to participate and four were chosen to volunteer. Two of the candidates were in their junior year of college, and two were in their senior year. Two weeks before the project started, all four candidates were brought together for an informational meeting to learn about the details and expectations of the project. No training was needed as the candidates were instructed not to teach any type of lesson during the project. All types of reading material were permitted: picture books, comic books, recipes, newspapers, et cetera. The project began at the end of January and the project involved six meetings.

\section{Selection of the Male Students}

Two months before the project started, the Gannon professor contacted two principals from schools in Erie, Pennsylvania. Each principal selected two male students in Grades 3 or 4 to participate, for a total of four male students. Students were chosen to participate due to their lack of motivation to read or because they were identified as struggling readers. The principals

told the male students that a new reading project was being developed that would include male relatives and they had been chosen to participate if they were interested. All four students expressed their desire to participate.

\section{Procedure}

In this section, we will present the role of each participant in the project and the steps required throughout the project.

\section{Roles of Al/ Participants}

Each member of the trio had a well-defined role. The student's role was to actively participate in the project by choosing materials based on his interests and by reading with the adults. The teacher candidate's role was to support the student in his choices of reading materials, and to read with the student and the other adult. The teacher candidate was acting like a "Big Brother" 
of reading for the student and as a collaborator for the parent. Finally, the male relative strived to show that men can enjoy reading through their active involvement in the meetings and by reading regularly with the student.

\section{Research Process in Three Steps}

Step 1: Introductory session. The first meeting was held within the school. The project was explained to school personnel, adults, students, and teacher candidates. The male trios were formed by pairing a teacher candidate with a student. No pre-set criteria were used to form the male trios; instead the participants were allowed to naturally gravitate to each other.

Step 2: Each of the trios decided among themselves where and when they would meet, although most meetings ended up being held at a local bookstore.

Step 3: Focus group. The last session was a group luncheon held at a local restaurant to discuss the whole experience and future improvements. Sixteen people attended the lunch. The focus groups created an opportunity to gauge everyone's impressions of the project by interviewing all the participants and assessing the changes observed among the students. The researchers also took this opportunity to identify ways to improve the family literacy project. At this meeting, the students each received four books that had been chosen to match their interests in reading and a certificate of participation was given to each student and the male relatives. Teacher candidates received a certificate and a letter for their professional portfolio.

Moreover, it is important to note that, once created, each of the four male trios had its own way of functioning. The teacher candidate was told not to teach a lesson and the student was the one in control because he was the boss of what to read. Trios were required to meet a minimum of four times (to respect the availability of working male relatives) over a period of 4 months (duration of the university semester). They could meet more often if desired. Due to the requirement to meet in public locations, most meetings were held at a local bookstore.

\section{Materials}

The results come from the mid-project semi-directed interviews with the teacher candidates; discussion from a focus group involving all participants at the end of the project; and teacher candidates' logbooks.

\section{Semi-Directed Interviews}

At mid-project, researchers met with the teacher candidates for a semi-directed interview. This kind of interview has a list of open-ended questions that are prepared in advance (Van der Maren, 1996). The semi-directed interview is a verbal interaction between the researcher and the person being interviewed (Savoie-Zajc, 2006). The goal of this interview was to gather an 
update concerning the project and to allow each participant to share his experience or ask questions. The interview was audio-recorded. Due to the lack of availability of male relatives, follow-up interviews with them were done over the phone.

\section{Focus Group}

The goal of a focus group is to promote a comfortable atmosphere of disclosure in which people can share their attitudes, experiences, and ideas about a topic of discussion. In fact, participants "influence and are influenced," while researchers play various roles, including being an observer, a listener, a moderator and, sometimes, an inductive analyst (Krueger \& Casey, 2000). For this study, the focus group was held at the end of the project. All participants met in a restaurant to share their experience. Participants were encouraged to give honest feedback and were told upfront that no answer would be considered wrong or inaccurate. Written notes were taken to ensure accuracy of the responses. Questions were asked to all the participants and the goal of these questions was to get different points of view regarding the whole experience.

\section{Logbooks}

Each teacher candidate maintained a logbook throughout the project. The goal of a logbook is to describe important events or activities, different contexts, and to note impressions, feelings, and discoveries (Legendre, 2005; Savoie-Zajc, 2004). The logbooks completed by the teacher candidates covered the whole experience, from beginning to the end. Prompts were shared with the teacher candidates to offer a focus for their reflections. The opportunity to complete a logbook was offered to the male relatives and the sons, but they opted not to complete it.

It should be noted that there was no cost for the male teacher candidates, male relatives, or students to participate in this project, nor was any person paid to participate in this project. A small grant from Kappa Delta Pi International Honor Society in Education was received and the schools contributed financially to defray the cost of purchasing reading materials and paying for the luncheon, which were the only costs incurred throughout the project.

\section{Data Analysis}

In this research, we used content analysis. Content analysis is a research technique used to analyze and interpret the meaning of oral and written messages (Bardin, 2013; Denzin \& Lincoln, 2005). In this case, we created a grid analysis with different themes (reading practices, relationship, motivation, reading interests, etc.) and we coded the content of the semi-directed interviews with the teacher candidates, the focus group discussion involving all participants at the end of the project, and the teacher candidates' logbooks. 


\section{Results}

The following are descriptions of the four trios and their experiences as told by the teacher candidates in their semi-directed interview and through their logbooks.

\section{Description of Trio 1}

Trio 1 met every week from 4:00 p.m. to 5:30 p.m. (90 minutes). In total, they met eight times as a trio at Barnes \& Noble. This trio maintained a specific format for each session. During the first meeting, the teacher candidate began with a verbal reading interest inventory. At the beginning of each subsequent session, they discussed what they read the week before and the opportunities they experienced for reading in class and at home. Then, the student chose one book, the father chose one book, and the teacher candidate chose one book. After looking at the three books, the student decided which book he really wanted to read. Then, the trio used a shared reading format with each member reading two pages. The more interested the student was, the bigger share of the reading he would take on. When the book was finished, they discussed what they liked and disliked about it. The trio then discussed the books that the father and teacher candidate had initially picked to read and this information was used to decide what they might read next time. At the end of each session, they chose a time and day for the next week's meeting. After the first meeting, the father talked to his son about the experience and since his child was agreeable they continued to meet every week and followed the same format. This was important because it maintained the concept of the student being in control.

\section{Description of Trio 2}

Trio 2 met at a local library for their first meeting, then chose to change the location to Barnes $\&$ Noble. In total, they met four times as a trio. During the first meeting, they read three different books. The student enjoyed reading, but the teacher candidate noted that the student stumbled on words when he read too fast. For the second meeting, they read some of the books from the "Black Lagoon" series and "The Sparkling Fish." The student read more than his dad and the teacher candidate because he felt confident that he could read almost the whole book without any assistance. During the third meeting, they read "The Stinky Cheese" which the student enjoyed very much. For the fourth meeting, they picked out "Diary of a Worm" and the student enjoyed this reading because there were funny lines and entertaining pictures. The teacher candidate noted the student behaved very well and he was very easy to get along with: "He was really, really well behaved with me, he was able to pay attention." He never asked if it was time to leave. The father found this to be particularly of interest as this student was exhibiting behaviour issues at school. Each member of the trio took turns reading, typically one page each. The length of each meeting was between 90 minutes and 120 minutes every 2 to 3 weeks. 


\section{Description of Trio 3}

Trio 3 met at the university's library for their first meeting, then chose to change the location to Barnes \& Noble. In total, they met five times as a trio. For the first meeting, the library was full so they chose to find three seats in a corner and took advantage of this time to get to know each other. They discussed each other's reading interests and other topics such as sports and hobbies for about an hour. For the second meeting, the student brought a book with him. The book was 326 pages and was a part of the "Geronimo Stilton" series. They read part of this book together with each member taking a turn. During the third meeting, they reviewed what the student and his father had read at home and then continued to read the same book. They finished the book and then summarized the story. They chose a new book (staying with the "Geronimo Stilton" series) for the father and the son to read at home and then continued with the same format for the fourth meeting. The father and the son finished reading the story at home. During the fifth meeting, they discussed the end of the story and chose a new book from "The Magic Tree House" series: "Dinosaurs Before Dark." The trio read this book together in one session since it was only 100 pages in length. The student enjoyed it and chose more books from the series that he was interested in reading. Each meeting was 45 to 60 minutes on average.

\section{Description of Trio 4}

Trio 4 was composed of an uncle as the adult male figure in the student's life. In total, they met four times for an average of 90 minutes per session at Barnes \& Noble. The uncle and the teacher candidate allowed the student to first freely explore the children's section in the store and then let him choose which book he wanted to read. When reading, they took turns and they used different accents and funny voices to make reading more fun. The teacher candidate commented, "It was good to see his uncle being animated with him [nephew]." "One of the books the student chose was SpongeBob SquarePants. The uncle did the voices of the characters from the show." Moreover, the student really likes to draw, use his imagination, and his creativity, which he did frequently during these meetings. Using this as a catalyst, the teacher candidate asked the student questions such as: "What do you think the character looks like?" They both drew a picture and then found themselves laughing as they compared their drawings. The teacher candidate said during the semi-directed interview: "I want to keep doing this to show that books can spark imagination and creativity." By looking at the drawing, the teacher candidate was able to see that the student understood what he read.

Table 1 provides an overview of the four trios' sessions. 


\section{Table 1}

Summary of the Four Trios

\begin{tabular}{|c|c|c|c|c|}
\hline & Trio 1 & Trio 2 & Trio 3 & Trio 4 \\
\hline $\begin{array}{l}\text { Number of } \\
\text { meetings }\end{array}$ & 8 & 4 & 5 & 4 \\
\hline Location & $\begin{array}{c}\text { In the } \\
\text { community (at } \\
\text { Barnes \& } \\
\text { Noble) }\end{array}$ & $\begin{array}{c}\text { In the } \\
\text { community (at } \\
\text { Barnes \& } \\
\text { Noble) }\end{array}$ & $\begin{array}{c}\text { In the } \\
\text { community (at } \\
\text { Barnes \& } \\
\text { Noble) }\end{array}$ & $\begin{array}{c}\text { In the } \\
\text { community (at } \\
\text { Barnes \& } \\
\text { Noble) }\end{array}$ \\
\hline $\begin{array}{l}\text { Number of } \\
\text { minutes }\end{array}$ & $\begin{array}{c}\text { Approx. } \\
90 \text { minutes }\end{array}$ & $\begin{array}{c}\text { Between } \\
90-120 \\
\text { minutes }\end{array}$ & $\begin{array}{c}\text { Approx. } \\
45-60 \text { minutes }\end{array}$ & $\begin{array}{c}\text { Approx. } \\
90 \text { minutes }\end{array}$ \\
\hline $\begin{array}{l}\text { Shared-book } \\
\text { reading }\end{array}$ & Yes & Yes & Yes & Yes \\
\hline
\end{tabular}

\section{Discussion}

The following are several of the comments shared by the participants during the luncheon focus group discussion of the experiences in the project as well as observations gathered from the researchers. This discussion is separated by themes: reading practices inside the male trios, the relationship inside these trios, and implications of the project.

\section{Reading Practices Inside the Male Trios}

In Trio 1, the student said he truly enjoyed discovering new books. His father confirmed that the exposure to a large variety of different kinds of books broaden his son's horizons. He now has a list of different authors and genres to choose from that he did not know about before the project (e.g., a book with multi-stories). The student chose books by using the commonly used strategy of examining the front cover and reading the back cover. He also felt that there were some books he deemed "weird" and he would not want to read again. The father was happy to see a real difference with his son in class as well. According to the student's teacher, he was less afraid to read, was more confident, less shy about asking questions in class, and more actively participating in class after the project began. The father truly saw a significant improvement in his son's reading and he believes the project had a positive impact on his son. Furthermore, the teacher candidate noticed that the student started to use decoding and context clues strategies when he misread a word, something he did not do when the project first began. 
By the end of the project, it was stated that the student in Trio 2 was using his eyes only instead of his index finger when reading. The student was reading clearly to his father and the teacher candidate. The student understood what he was reading because after every page, he would explain to his father and the teacher candidate what was going on in the story. This is a significant improvement because before the beginning of the project, his teacher was concerned that this student was not understanding what he was reading (Rasinski, 2017). One possible explanation for this could be that the student was simply not interested in what he was reading in school (Gritter et al., 2017) and thus was not making an effort to understand what he was reading in class. More importantly, the father and the son truly enjoyed the project and said that they will definitely continue to read together.

At the beginning of the project, the pre-service teacher noticed that the student in Trio 3 was using his index finger when reading, and his speed and pace in reading were off as he would read too fast and not pause at the end of sentences. However, by the end of the project, the student no longer used his finger to read. His speed and pace had also greatly improved, although he was still reading too fast at times and guessing words incorrectly after glancing at the beginning of the word. For instance, he would say "sometimes" instead of "something." Due to the directive that the teacher candidate was not to teach a lesson, this behaviour was only indirectly addressed. The fact that the father and the student read books at home and then reviewed them with the teacher candidate revealed the student's improved comprehension skills in reading. According to his teacher, the student regularly talked about the project in class. He told her what his father was reading at home and what was happening in the trio meetings during the project. Moreover, the father said he saw a significant improvement in his son's reading. In fact, his son was struggling and the father stated that the project definitely helped his son become more confident when reading. After the project, he decided to continue to read to his son every day after dinner. Finally, the student said that what he truly liked was the fact that he could read what he really enjoyed (Beauregard \& Carignan, 2010; Carignan \& Beauregard, 2010; Demers, 2009), without having any evaluation (Bloome et al., 2000; Serafini, 2013; Ward \& Wason-Ellam, 2005).

In Trio 4, the student said he truly enjoyed reading during the project and particularly liked doing it within the trio. He said: "it was fun to take turns in reading." The student appreciated being able to choose a book that he liked (Baugh, 2017). Moreover, the student liked that he was "in control" because he decided what they would read during the trio's meeting and how they would read. For example, the uncle and the nephew used the southern accent of the United States when they were reading all together. The student said that he felt that he was a much better reader after the project. The uncle also enjoyed the project overall.

Some commonalities can be extracted from the trios. Interestingly, some books appreciated by the male students in general had humorous school-related storylines. It is possible that in this case, the students may identify with the characters because these characters were able to do 
things in the story that the children would like to do, but cannot do, in their own schools. Furthermore, all of the students seem to have appreciated the role they were given as "the leader" or "the boss." Most importantly, most pre-service teachers highlight the improvement in reading skills from the few sessions they have met and all significant male figures mention an increase in motivation. The results are very promising both from a research standpoint and from a practice perspective.

\section{Relationship Inside the Male Trios}

In Trio 1, throughout the project, there was a great relationship between the father and the son and a good chemistry within the trio, which is also a byproduct of reading together (Karther, 2002; Morgan et al., 2009; Saracho, 2008). In Trio 2, the father felt that the teacher candidate did a great job in relating to his son and said that this was unusual because his son is usually wary of new people. After the project, the father in Trio 3 was happy to be more involved in his son's homework (Hoover-Dempsey et al., 2005) and felt more confident (Letouzé, 2007; Rasinski \& Stevenson, 2005) and competent in his role as a reading model (Clark \& Picton, 2012). He felt more at ease with this role. The father and the teacher candidate also said the student was less intimidated and felt less pressure because of the open structure of the project. In Trio 4, the uncle really liked the fact that they were trying to keep the meetings spontaneous within a relaxed environment without pressure (Beauregard \& Carignan, 2010) of results. In addition, in this trio, all three members truly enjoyed the project and the time spent together reading. During several of their meetings, the student repeatedly said: "I don't want to leave! How many times can we meet? Can we meet more than that?" The uncle and the student were very vocal about the fun they had doing this project together. At the end of the project, the uncle said to the teacher candidate that he realized how important it is to read to his nephew every night. Finally, during the focus group, the student in Trio 4 said that he really liked that they were all eating together to celebrate the end of the project.

In sum, at the end of the project, the four boys were more motivated to read what they truly liked in the context of this family and community literacy project based on shared book reading and male role models. This could be explained by the fact that the boys could read whatever they wanted to read (Baugh, 2017; Skuy, 2007) without any judgment or pressure. Moreover, regarding the reading practices, all the male trios used a shared book reading format. When the student felt more comfortable to read, he decided to read more and longer. If he did not like the book he picked in the first place, he had the choice to put it back and pick a new one because he was the one in control.

\section{Implications for Current and Pre-Service Teachers}

This family literacy project helped the male pre-service teachers better understand the importance of making reading enjoyable for all students and how to facilitate reading for all 
students, but particularly for boys. They also learned the importance of including a plethora of books in their future classroom library with different themes, levels, and genres that will engage and motivate the male students in the reading process and help with their confidence. The project also gave the pre-service teachers the opportunity to work with a male student and male relative at the same time. There are further applications of this project, to be discussed in future publications, related to parent involvement and the importance of giving pre-service teachers experience working with parents. Moreover, this project showed the importance of building good relationships with parents and seeing them as a partner to promote the educational success of their children. In sum, everything leads us to believe that the observations are generalizable to teachers and that the knowledge that the pre-service teachers acquired will be transferred in their practice.

\section{Improvements and Limitations}

During the culminating luncheon, one father mentioned that we should try to involve more male trios and more people in the project. According to him, this project should be bigger because it helps with the father-son relationship; it is not just about reading books. Another father said that the trios should meet more often, perhaps every week, to read more. A teacher candidate would like to see this project expanded to early childhood students. As for limitations, first, using a focus group could be seen as an issue because of the possibility of the impact of social desirability in face-to-face interviews (Stodel, 2015). In other words, participants could "give socially desirable responses instead of choosing responses that are reflective of their true feelings" (Grimm, 2010, p. 2) regardless of being told that there were no inaccurate answers. Second, it was not possible to acquire pre-project data to assess the evolution of the students' reading abilities. However, with the current methodology, it was possible to acquire relevant data, not only from the members of the trios but also from the teachers and school principals. Third, the sample was small, which restricts the generalizability of "Reading with my buddy." It would be interesting to conduct the project with a larger sample and methodological tools allowing for the measurement of pre-project and post-project reading skills, motivation, and the evolution of the relationship inside the trios.

\section{Conclusion}

Most of the positive results obtained in Pennsylvania were similar to the results obtained in Quebec even though the country, the language, and the context (community instead of family home) were different. In fact, the project, in both instances, was done without pressure, and always remained spontaneous, positive, and open. Every trio had its own unique way of functioning. Thus, we can say that "Reading with my buddy" is an effective family literacy project that could be replicated in different countries and different languages. In this family literacy project, the students acquired a feeling of competence in reading and truly enjoyed the 
experience of reading within a male trio. They also reported enjoying the special relationship that was created. The teacher candidates learned the importance of allowing boys to make their own choices in reading material, the impact of a male role model, and the value of making a positive connection with parents. The male relatives seemed to learn how rewarding it was to read and interact with their child. Every trio had its own unique way of functioning. It was noted that the project had a positive influence regarding the family-school relationship.

\section{Take Action!}

Here are some hints or recommendations for school settings and the community to implement effective family literacy programs with male reading models:

- Implement the program in the community or at home to differentiate it from school literacy;

- Inform fathers or significant relative about the project by explaining the purpose, the objectives, and the role of every participant;

- Take into account families' availability: (a) parents' work schedules; (b) other family activities; (c) needs of other children;

- Provide materials to the parents and the children: (a) easy access to resources and materials is a determining factor for low-income families; (b) receiving books is a motivation for children and a reward for the parents; (c) vary the reading media (magazines, newspapers, etc.);

- Provide refreshments, transportation, meals, daycare and moral support if the project takes place outside the home (the family has nothing to pay);

- Emphasize the father's role in literacy development, particularly for boys.

\section{References}

Adra, N. (2004). Literacy through poetry: A pilot project for rural woman in the Republic of Yemen. Women's Studies Quarterly, 32(1 /2), 226-243.

Anderson, J., Anderson, A., Friedrich, N., \& Eun, K. J. (2010). Taking stock of family literacy: Some contemporary perspectives. Journal of Early Childhood Literacy, 10(1), 33-53. https:// doi.org/ $10.1177 \% 2 F 1468798409357387$

Anderson, J., Anderson, A., Lynch, J., \& Shapiro, J. (2004). Examining the effect of gender and genre on interactions in shared book reading. Reading Research and Instruction, 43(4), 1 20. https://doi.org/10.1080/19388070409558414

Baker, L. (2003). The role of parents in motivating struggling readers. Reading and Writing Quarterly, 19(1), 87-106. https://doi.org/10.1080/10573560308207

Baker, L., \& Scher, D. (2002). Beginning readers' motivation for reading in relation to parental beliefs and home reading experiences. Reading Psychology, 23(4), 239-269. https:/ / doi.org/10.1080/713775283 
Bardin, L. (2013). L'analyse de contenu (2nd ed.). Presses universitaires de France.

Baron, J. (1996). Sexism attitudes towards reading in the adult learner population (ED393092). ERIC. https: / / eric.ed.gov/?id=ED393092

Barone, D. M. (2011). Case study research. In N. K. Duke \& M. H. Mallette (Eds.), Literacy research methodologies (2nd ed., pp. 7-27). The Guilford Press.

Baugh, T. (2017). Supporting the affective needs of a struggling reader. The Reading Teacher, 7l(2), 229-230. https://doi.org/10.1002/trtr.1607

Beauregard, F., \& Carignan, I. (2010, May). Lire avec fiston: un projet novateur! Vie pédagogique, 154. https://tinyurl.com/ywcweoa4

Beauregard, F., \& Carignan, I. (2012, April 4). Reading with junior: A project in family literacy. Education Canada, 52(2). https://www.edcan.ca/articles/reading-with-junior-a-projectin-family-literacy/

Beauregard, F., Carignan, I., \& Létourneau, M.-D. (2011). Recension des écrits scientifiques sur la littératie familiale et communautaire. Ministère de l'Éducation, du Loisir et du Sport (MELS). https: / / tinyurl.com/y6I3yjsa

Bergin, C. (2001). The parent-child relationship during beginning reading. Journal of Literacy Research, 33, 681-706. https://doi.org/10.1080\%2F10862960109548129

Bloome, D., Katz, L., Solsken, J., Willett, J., \& Wilson-Keenan, J. (2000). Interpellations of family/community and classroom literacy practices. The Journal of Educational Research, 93(3), 155-163. https://doi.org/10.1080/00220670009598704

Boerma, I. E., Mol, S. E., \& Jolles, J. (2016). Teacher perceptions affect boys' and girls' reading motivation differently. Reading Psychology, 37(4), 547-569. https://doi.org/10.1080/02702711.2015.1072608

Bouchamma, Y., Poulin, V., \& Ruel, C. (2014). Impact of reading strategy use on girls' and boys' achievement. Reading Psychology, 35(4), 312-331. https://doi.org/10.1080/02702711.2012.724043

Bursuck, W. D., Robbins, S., \& Lazaroff, K. (2010). Meeting the needs of struggling readers in high school: What are rural schools doing? The Rural Educator, 37(2), 27-32. https:/ / doi.org/10.35608/ruraled.v31i2.954

Bus, A. G., \& Van IJzendoorn, M. H. (1998). Mother-child interaction, attachment, and emergent literacy: A cross-sectional study. Child Development, 59, 1262-1272. https://doi.org/10.2307/1130489

Bus, A. G., Van IJzendoorn, M. H., \& Pellegrini, A. D. (1995). Joint book reading makes for success in learning to read: A meta-analysis on intergenerational transmission of literacy. Review of Educational Research, 65, 1-21. https://doi.org/10.3102\%2F00346543065001001 
Cairney, T. H. (2002). Bridging home and school literacy: In search of transformative approaches to curriculum. Early Child Development and Care, 172(2), 153-172.

Cairns, R. B., Cairns, B. D., \& Neckerman, H. J. (1989). Early school dropout: Configurations and determinants. Child development, 1437-1452. https://doi.org/10.1111/j.14678624.1989.tb04015.x

Carignan, I., \& Beauregard, F. (2010). Lire avec fiston: intégrer la famille dans la lecture. In M. Hébert \& L. Lafontaine (Eds.), Pratiques et outils pédagogiques en littératie dans une perspective d'inclusion (pp. 97-109). Presses de I'Université du Québec.

Carignan, I., Beauregard, F., \& Quick, R. (2013). Comment la communauté peut-elle jouer un rôle important dans un projet de littératie familiale? Vivre le primaire, 26(3), 35-36.

Carignan, N., Deraîche, M., \& Guillot, M.-C. (2015). Jumelages interculturels. Presses de l'Université du Québec.

Carrington, B., \& McPhee, A. (2008). Boys' "underachievement" and the feminization of teaching. Journal of Education for Teaching, 34(2), 109-120. https:/ / doi.org/10.1080/02607470801979558

Chiu, C.-H., \& Ko, H.-W. (2005). Relations between parental factors and children's reading behaviors and attitudes: Results from PIRLS 2005 field test in Taiwan. Department of Education, National Chengchi University.

Chiu, M. M. (2018). Contextual influences on girls' and boys' motivation and reading achievement: Family, schoolmates, and country. In P. Orellana \& P. Baldwin Lind (Eds.), Reading achievement and motivation in boys and girls (pp. 49-63). Springer. https:/ / doi.org/10.1007/978-3-319-75948-7_3

Clark, C., \& Picton, I. (2012). Family matters: The importance of family support for young people's reading. Findings from the National Literacy Trust's 2011 annual literacy survey. National Literacy Trust. https://tinyurl.com/yxcg39za

Collins, L., \& Matthey, S. (2001). Helping parents to read with their children: Evaluation of an individual and group reading motivation program. Journal of Research in Reading, 24(1), 65-81. https://doi.org/10.1111/1467-9817.00133

Conseil canadien sur l'apprentissage (CCA). (2010). Pas seulement ludiques: Les bandes dessinées et la composition de textes suivis chez les garçons. Carnet du Savoir. www.cclcca.ca/CCL/Reports/LessonsInLearning/LinL20100721 Comics-2.html

Demers, D. (2009). Au bonheur de lire. Comment donner le gout de lire à son enfant de 0 à 8 ans. Québec Amérique.

De Naeghel, J., Van Keer, H., Vansteenkiste, M., \& Rosseel, Y. (2012). The relation between elementary students' recreational and academic reading motivation, reading frequency, 
engagement, and comprehension: A self-determination theory perspective. Journal of Educational Psychology, 104(4), 1006-1021. https://doi.org/10.1037/a0027800

Denzin, N. K., \& Lincoln, Y. S. (2005). Introduction: The discipline and practice of qualitative research. In N. K. Denzin and Y. S. Lincoln (Eds.), The SAGE handbook of qualitative research (p. 1-32). Sage.

Dyson, A. (1995). Children out of bounds: The power of case studies in expanding visions of literacy development. In K. Hinchman, D. Leu, \& C. Kinzer (Eds.), Perspectives on literacy research and practices (pp. 39-53). National Reading Conference.

Edmunds, K. M., \& Bauserman, K. L., (2006). What teachers can learn about reading motivation through conversations with children. The Reading Teacher, 59(5), 414-424. https://doi.org/10.1598/RT.59.5.1

Epstein, J. (2001). School, family and community partnerships. Westview Press.

Ezell, H. K., \& Justice, L. M. (2000). Increasing the print focus of adult-child shared book reading through observational learning. American Journal of Speech-Language Pathology, 9, 36-47. https://doi.org/10.1044/1058-0360.0901.36

Farukh, A., Sibtain, M., Qasim, H. M., \& Shahzad, A. K. (2020). Involvement of social and cognitive factors in reading skills of boys and girls: A comparative study. Review of Economics and Development Studies, 6(1), 147-152. https://doi.org/10.47067/reads.v6i1.192

Frosch, C. A., Cox, M. J., \& Goldman, B. D. (2001). Infant-parent attachment and parental and child behaviour during parent-toddler storybook interaction. Merrill-Palmer Quarterly, 47, 445-474.

Gilmore, J. (2010). Trends in dropout rates and the labour market outcomes of young dropouts (Catalogue no. 81-004-X). Statistics Canada. https://tinyurl.com/y54g9c4z

Grimm, P. (2010). Social desirability bias. In Wiley international encyclopedia of marketing. Wiley. https://doi.org/10.1002/9781444316568.wiem02057

Gritter, K., Vriend Van Duinen, D., Montgomery, K., Blowers, D., \& Bishop, D. (2017). Boy troubles? Male literacy depictions in children's choices picture books. The Reading Teacher, 70(5), 571-581. https://doi.org/10.1002/trtr.1559

Gurian, M., \& Stevens, K. (2004). With boys and girls in mind. Educational Leadership, 62(3), 21-66. https://tinyurl.com/6uyd86w

Hoover-Dempsey, K. V., Walker, J., Sandler, H. M., Whetsel, D., Green, C., Wilkins, A., \& Closson, K. (2005). Why do parents become involved? Research findings and implications. Elementary School Journal, 106(2), 105-131. https://doi.org/10.1086/499194 
Justice, L. M., \& Ezell H. K. (2000). Enhancing children's print and word awareness through home-based parent intervention. American Journal of Speech-Language Pathology, 9 , 257-269. https://doi.org/10.1044/1058-0360.0903.257

Karther, D. (2002). Fathers with low literacy and their young children. The Reading Teacher, 56(2), 184-193.

Korhonen, J., Linnanmäki, K., \& Aunio, P. (2014). Learning difficulties, academic well-being and educational dropout: A person-centred approach. Learning and Individual Differences, 31 , 1-10. https://doi.org/10.1016/j.lindif.2013.12.011

Krueger, R., \& Casey, M. A. (2000). Focus groups: A practical guide for applied research (3rd ed.). Sage.

Lavoie, A., \& Fontaine, C. (2016). Mieux connaitre la parentalité au Québec. Un portrait à partir de l'Enquête québécoise sur l'expérience d'enfants de 0-5 ans 2015. Institut de la statistique du Québec.

https:/ / www.aqcpe.com/content/uploads/2016/12/parentialite.pdf

Legendre, R. (2005). Dictionnaire actuel de l'éducation (3rd ed.). Guérin.

Letouzé, S. (2007). Pour mon enfant d'abord. Étude de l'impact de l'alphabétisation familiale sur les familles vivant en milieu minoritaire. Étape 1, 2004-2005. http://www.bdaa.ca/biblio/recherche/cfafbo/enfant3/enfant3.pdf

Logan, S., \& Johnston, R. (2009). Gender differences in reading ability and attitudes: Examining where these differences lie. Journal of Research in Reading, 32(2), 199-214. https://doi.org/10.1111/j.1467-9817.2008.01389.x

Maxwell, J. A. (1992). Understanding and validity in qualitative research. Harvard Educational Review, 62, 279-299. https://doi.org/10.17763/haer.62.3.8323320856251826

McGeown, S., Goodwin, H., Henderson, N., \& Wright, P. (2012). Gender differences in reading motivation: Does sex or gender identity provide a better account? Journal of Research in Reading, 35(3), 328-336. https://doi.org/10.1111/j.1467-9817.2010.01481.x

McKenna, E. (1997). Gender differences in reading attitudes (ED407653). ERIC. https:/ /files.eric.ed.gov/fulltext/ED407653.pdf

Mistry, M., \& Sood, K. (2015). Why are there still so few men within Early Years in primary schools: Views from male trainee teachers and male leaders? Education 3-13, 43(2), $115-$ 127. https://doi.org/10.1080/03004279.2012.759607

Morgan, A., Nutbrown, C., \& Hannon, P. (2009). Fathers' involvement in young children's literacy development: Implications for family literacy programs. British Educational Research Journal, 35(2), 167-185. https://doi.org/10.1080/01411920802041996 
Nalipay, M. J. N., Cai, Y., \& King, R. B. (2020). Why do girls do better in reading than boys? How parental emotional contagion explains gender differences in reading achievement. Psychology in the Schools, 572), 310-319. https://doi.org/10.1002/pits.22330

Ozturk, G., Hill, S., \& Yates, G. C. (2016). Girls, boys and early reading: parents' gendered views about literacy and children's attitudes towards reading. Early Child Development and Care, 186(5), 703-715. https://doi.org/10.1080/03004430.2015.1053477

Pronovost, G. (with Tétreault, K., Routhier, C., \& Desrosiers, H.). (2013, July). Le développement de pratiques culturelles chez les enfants: Analyse de données de l'Étude longitudinale du développement des enfants du Québec. Optique Culture, 26.

https://manuscritdepot.com/documentspdf/optique-culture-26.pdf

Rasinski, T. (2017). Readers who struggle: Why many struggle and a modest proposal for improving their reading. The Reading Teacher, 70(5), 519-524.

https:/ / doi.org/ 10.1002/trtr.1533

Rasinski, T., \& Stevenson, B. (2005). The effects of Fast Start Reading: A fluency based home involvement reading program, on the reading achievement of beginning readers. Reading Psychology: An International Quarterly, 26(2) 109-125.

https:/ / doi.org/10.1080/02702710590930483

Reilly, D., Neumann, D. L., \& Andrews, G. (2019). Gender differences in reading and writing achievement: Evidence from the National Assessment of Educational Progress (NAEP). American Psychologist, 74(4), 445-458. https://doi.org/10.1037/amp0000356

Roy-Charland, A., Saint-Aubin, J., \& Evans, M. A. (2007). Eye movements in shared book reading with children from kindergarten to Grade 4. Reading and Writing, 20(9), 909-931. https://doi.org/10.1007/s11145-007-9059-9

Sandelowski, M. (2000). Focus on research methods: Whatever happened to qualitative description? Research in Nursing \& Health, 23, 334-340. https://doi.org/10.1002/1098240x(200008)23:4\%3C334::aid-nur9\%3E3.0.co;2-g

Saracho, O. (2008). A literacy program for fathers: A case study. Early Childhood Education Journal, 35, 351-356. https://doi.org/10.1007/s10643-007-0194-3

Savoie-Zajc, L. (2004). La recherche qualitative/interprétative en éducation. In T. Karsenti \& L. Savoie-Zajc (Eds.), La recherche en éducation: étapes et approches (pp. 123-150). Éditions du CRP.

Savoie-Zajc, L. (2006). L'entrevue semi-dirigée. Recherche sociale. In B. Gauthier (Ed.), De la problématique à la collecte des données (pp. 293-316). Presses de l'Université du Québec.

Serafini, F. (2013). Supporting boys as readers. The Reading Teacher, 67(6), 465-468. https://doi.org/10.1002/TRTR.1187 
Skuy, D. (2007). Boys don't read-It's true! Teaching \& Learning, 4(1), 23-24. https://doi.org/10.26522/tl.v4i1 1.13

Smith, L. (2017). "Book club rules and tutoring drools": An intervention mixed methods study of the effects of an after-school book club on third-grade boys' reading achievement, attitudes, preferences [Unpublished doctoral dissertation]. Sam Houston State University.

Stebbins, R. A. (2001). Exploratory research in the social sciences. Sage.

Stodel, M. (2015). But what will people think? Getting beyond social desirability bias by increasing cognitive load. International Journal of Market Research, 572), 313-321. https:/ / doi.org/10.2501/IJMR-2015-024

Stoet, G., \& Geary, D. C. (2013). Sex differences in mathematics and reading achievement are inversely related: Within-and across-nation assessment of 10 years of PISA data. PloS One, 8(3), e57988. https://doi.org/10.1371/journal.pone.0057988

Summers, K. (2013). Adult reading habits and preferences in relation to gender differences. Reference \& User Services Quarterly, 52(3), 243-249. https://doi.org/10.5860/rusq.52.3.3319

Van der Maren, J.-M. (1996). Méthodes de recherche pour l'éducation (2nd ed.). Les Presses de I'Université de Montréal.

van Hek, M., Buchmann, C., \& Kraaykamp, G. (2019). Educational systems and gender differences in reading: A comparative multilevel analysis. European Sociological Review, 35(2), 169-186. https://doi.org/10.1093/esr/jcy054

Van Kleeck, A., Stahl, S. A., \& Bauer, E. B. (2003). On reading books to children: Parents and teachers. Erlbaum.

Walsh, M. E., Lee-St John, T. J., Raczek, A., \& Foley, C. (2015). The long-term impact of systematic student support in elementary school: Reducing high school dropout (ED562544). ERIC. https://eric.ed.gov/?id=ED562544

Ward, A., \& Wason-Ellam, L. (2005). Reading beyond school: Literacies in a neighbourhood library. Canadian Journal of Education, 28(1/2), 92-108. https:/ files.eric.ed.gov/fulltext/EJ695663.pdf

Wasik, B. H., \& Van Horn, B. (2012). The role of family literacy in society. In B. Wasik (Ed.), Handbook of family literacy (2nd ed., pp. 3-17). Routledge.

Wells, G. (2009). The social context of language and literacy development. In O. A. Barbarin \& B. H. Wasik (Eds.), The handbook of child development and early education (pp. 271-302). Sage.

Wilhelm, J. D., \& Smith, M. W. (2014). Reading unbound: Why kids need to read what they want and why we should let them. Scholastic. 
Wiseman, A. M. (2009). "When you do your best, there's someone to encourage you":

Adolescents' views of family literacy. Journal of Adolescent \& Adult Literacy, 53(2), 132 142. https://doi.org/10.1598/JAAL.53.2.4

Wolter, I., Braun, E., \& Hannover, B. (2015, August 24). Reading is for girls!? The negative impact of preschool teachers' traditional gender role attitudes on boys' reading related motivation and skills. Frontiers in Psychology, 6.

https://doi.org/10.3389/fpsyg.2015.01267 